\title{
Synthesis, Characterization and Antifungal Activity of Adducts of Bis(acetylacetonato)oxovanadium(IV) with Heterocyclic Nitrogen Donor Ligands
}

\author{
RAJINDER SINGH*, NEERUPAMA, GURPREET KOUR, \\ POOJA SHARMA and RENU SACHAR \\ Department of Chemistry, University of Jammu, Jammu-180006, India \\ rschib2012@gmail.com
}

Received 19 March 2014 / Accepted 21 April 2014

\begin{abstract}
Monomeric six coordinated adducts of bis(acetylacetonato)oxovanadium(IV) having general formula, $\left[\mathrm{VO}(\mathrm{acac})_{2}(\mathrm{~L})\right],[\mathrm{L}=$ pyrrolidine, morpholine, 2,4,6-trimethylpyridine, 2,4, 2,6, 3,4, 3,5-dimethylpyridines, 2-ethylpyridine, 2-methylpyridine, 3-methylpyridine 2, 3, 4-cyanopyridine, quinoline, isoquinoline] have been synthesized and characterized by elemental analysis, IR, electronic spectroscopy, magnetic and conductivity measurements having 1:1 stoichiometry. The adducts were found to be paramagnetic and their magnetic moments at room temperature lie within the 1.72-1.87 B.M. range and this indicates the presence of one unpaired electron. The values are in accordance with the octahedral geometry. The magnetic moment measurements and electronic spectra depicts a octahedral geometry around the vanadium center. The investigated adducts have also tested against the fungus Fusarium oxysporum.
\end{abstract}

Keywords: Synthesis, Antifungal activity, Heterocyclic nitrogen donor ligand

\section{Introduction}

Acetylacetone is the simplest $\beta$-diketone, prepared by the Claisen condensation between ethyl acetate and acetone. The acetylacetonates are bidentate ligands which appear to form complexes with virtually all of the non radioactive metallic and metalloidal elements in the periodic table. Since the preparation of acetylacetone(2,4-pentanedione) and similar $\beta$ dicarbonyl compounds in the late half of twentieth century, chemists have shown considerable interest in their properties and reactions. The presence of $\beta$-carbonyl groups with at least one proton on the intermediate carbon atom, allows a tautomeric equilibrium of the keto and enol forms, which is the most important feature of acetylacetonates, since it is the enolate anion which forms complexes with metals ${ }^{1}$. Beta-Diketonate complexes are of growing interest due to favorable physical and chemical properties. Aside from the usage of these compounds as fuel additives and catalysts, beta-diketonate complexes also have been used as metal vapour sources ${ }^{2}$. Bis(acetylacetonate) cobalt(II) and its derivatives were recently proposed as mediators in controlled radical polymerization (CRP) of olefins. Cobalt-mediated CRP is based on the propensity of four-coordinated cobalt(II) complexes 
to reversibly capture organic radicals, there by buffering their concentration at the desired level $^{3}$. Here we report synthesis and investigation of the 1:1 bis(acetylacetonato) oxovanadium(IV) with some heterocyclic nitrogen donor ligands along with their antifungal activity.

\section{Experimental}

To a solution of vanadyl sulphate $\mathrm{VOSO}_{4}(0.025 \mathrm{~mol}, 4.075 \mathrm{~g}$ in $250 \mathrm{~mL}$ water $) 50 \mathrm{~mL}$ acetylacetone solution ( $0.5 \mathrm{~mol}$ in methanol) was added with constant stirring. To the resulting mixture aqueous solution of sodium acetate $(0.5 \mathrm{~mol}$ in $150 \mathrm{~mL}$ of water) was added. The mixture was heated briefly on steam bath, cooled to room temperature and placed in a refrigerator for 7-8 hours. The dark green precipitates were filtered off on a Buchner funnel, washed with water and dried in a vacuum desiccator over anhydrous calcium chloride.

\section{Preparation of adducts}

\section{[Bis(acetylacetonato)(pyrrolidine)oxovanadium(IV)] (1)}

Bis(acetylacetonato)oxovanadium(IV) $(2.65 \mathrm{~g}, 0.01 \mathrm{~mol})$ was dissolved in chloroform (about $160 \mathrm{~mL}$ ). To the resulting solution pyrrolidine $(0.712 \mathrm{~g}, 0.01 \mathrm{~mol})$ was added. The reaction mixture was stirred for about 30 minutes and then the solution was concentrated by distillation to obtain the maximium yield. Green colored precipitates of the adduct were formed. The precipitates were filtered and dried in a vacuum desiccator over anhydrous calcium chloride. The composition of the adduct was established to be $\mathrm{VO}\left(\mathrm{C}_{5} \mathrm{H}_{7} \mathrm{O}_{2}\right)_{2}$ $\left(\mathrm{C}_{4} \mathrm{H}_{9} \mathrm{~N}\right)$ by the elemental analysis, vanadium found $15.04 \%$; calculated $15.15 \%$.

\section{[Bis(acetylacetonato)(morpholine)oxovanadium(IV)] (2)}

Bis(acetylacetonato)oxovanadium(IV) $(2.650 \mathrm{~g}, 0.01 \mathrm{~mol})$ was dissolved in chloroform (about $160 \mathrm{~mL})$. To the resulting solution morpholine $(0.871 \mathrm{~g}, 0.01 \mathrm{~mol})$ was added. The mixture was stirred for about 20 minutes and then concentrated. Green coloured precipitates of the adduct were formed. The precipitates were filtered and dried in a vacuum desiccator over anhydrous calcium chloride. The composition of the adduct was established to be $\mathrm{VO}\left(\mathrm{C}_{5} \mathrm{H}_{7} \mathrm{O}_{2}\right)_{2}\left(\mathrm{C}_{4} \mathrm{H}_{9} \mathrm{NO}\right)$ by the elemental analysis, vanadium found $14.83 \%$; calculated $14.46 \%$.

\section{[Bis(acetylacetonato)(2,4,6-trimethylpyridine)oxovanadium(IV)] (3)}

Bis(acetylacetonato)oxovanadium(IV) $(2.65 \mathrm{~g}, 0.01 \mathrm{~mol})$ was dissolved in chloroform (about $160 \mathrm{~mL}) .2,4,6$-trimethylpyridine $(1.21 \mathrm{~g}, 0.01 \mathrm{~mol})$ was added to the resulting solution. Stir the mixture for about 15 minutes and then concentrated the resulting mixture. Green colored precipitates of the adduct were formed. The precipitates were filtered and dried in a vacuum desiccator over anhydrous calcium chloride. The composition of the adduct was established to be $\mathrm{VO}\left(\mathrm{C}_{5} \mathrm{H}_{7} \mathrm{O}_{2}\right)_{2}\left(\mathrm{C}_{8} \mathrm{H}_{11} \mathrm{~N}\right)$ by the elemental analysis, vanadium found $13.3 \%$; calculated $13.19 \%$.

\section{[Bis(acetylacetonato)(2,4-dimethylpyridine)oxovanadium(IV)] (4)}

The adduct was prepared by the same procedure followed for the compound 3 where 2,4-dimethylpyridine $(1.07 \mathrm{~g}, 0.01 \mathrm{~mol})$ was used instead of 2,4,6-trimethylpyridine. The solution was stirred for about 20 minutes and it was concentrated to get the maximium yield. The adduct obtained was dark green in color and its composition was established to be $\mathrm{VO}\left(\mathrm{C}_{5} \mathrm{H}_{7} \mathrm{O}_{2}\right)_{2}\left(\mathrm{C}_{7} \mathrm{H}_{9} \mathrm{~N}\right)$ by the elemental analysis, vanadium found $13.21 \%$; calculated $13.68 \%$. 


\section{Bis(acetylacetonato)(2,6-dimethylpyridine)oxovanadium(IV) (5)}

Bis(acetylacetonato)oxovanadium(IV) $(2.65 \mathrm{~g}, 0.01 \mathrm{~mol})$ was dissolved in chloroform (about $160 \mathrm{~mL}) .2,6$-Dimethylpyridine $(1.07 \mathrm{~g}, 0.01 \mathrm{~mol})$ was added. After stirring for about $25 \mathrm{~min}$, the solution was concentrated to get the better yield. The green colored precipitates of adduct were formed. The composition was found to be established as $\mathrm{VO}\left(\mathrm{C}_{5} \mathrm{H}_{7} \mathrm{O}_{2}\right)_{2}\left(\mathrm{C}_{7} \mathrm{H}_{9} \mathrm{~N}\right)$ by the elemental analysis, vanadium found $13.54 \%$; calculated $13.68 \%$.

\section{[Bis(acetylacetonato)(3,4-dimethylpyridine)oxovanadium(IV)] (6)}

The adduct was prepared by the same procedure followed for the compound 5 where 3,4dimethylpyridine $(1.07 \mathrm{~g}, 0.01 \mathrm{~mol})$ was used instead of 2,6-dimethylpyridine. After stirring for about $25 \mathrm{~min}$, the solution obtained was concentrated to get the maximium yield. The adduct obtained was dark green in color and its composition was established to be $\mathrm{VO}\left(\mathrm{C}_{5} \mathrm{H}_{7} \mathrm{O}_{2}\right)_{2}\left(\mathrm{C}_{7} \mathrm{H}_{9} \mathrm{~N}\right)$ by the elemental analysis, vanadium found $13.45 \%$; calculated $13.68 \%$.

\section{[Bis(acetylacetonato)(3,5-dimethylpyridine)oxovanadium(IV)] (7)}

The adduct was prepared by the same procedure followed for the compound 5 where 3,5dimethylpyridine $(1.07 \mathrm{~g}, 0.01 \mathrm{~mol})$ was used instead of 2,6-dimethylpyridine. The green colored adduct was formed and its composition was established to be $\mathrm{VO}\left(\mathrm{C}_{5} \mathrm{H}_{7} \mathrm{O}_{2}\right)_{2}\left(\mathrm{C}_{7} \mathrm{H}_{9} \mathrm{~N}\right)$ by elemental analysis vanadium found $13.83 \%$; calculated $13.68 \%$.

\section{[Bis(acetylacetonato)(2-ethylpyridine)oxovanadium(IV)] (8)}

Bis(acetylacetonato)oxovanadium(IV) $(2.65 \mathrm{~g}, 0.01 \mathrm{~mol})$ was dissolved in chloroform (about $160 \mathrm{~mL}$ ). To the resulting solution 2-ethylpyridine $(1.21 \mathrm{~g}, 0.01 \mathrm{~mol})$ was added. The mixture was stirred for about 30 minutes. The resulting solution was concentrated. Green colored precipitates of the adduct were formed. The precipitates were filtered and dried in a vacuum desiccator over anhydrous calcium chloride. The composition of the adduct was established to be $\mathrm{VO}\left(\mathrm{C}_{5} \mathrm{H}_{7} \mathrm{O}_{2}\right)_{2}\left(\mathrm{C}_{8} \mathrm{H}_{11} \mathrm{~N}\right)$ by the elemental analysis, vanadium found $12.32 . \%$; calculated $13.68 \%$.

\section{[Bis(acetylacetonato)(2-methylpyridine)oxovanadium(IV)] (9)}

Bis(acetylacetonato)oxovanadium(IV) (2.65 g, $0.01 \mathrm{~mol}$ ) was dissolved in chloroform (about $160 \mathrm{~mL})$. To the resulting solution 2-methylpyridine $(0.93 \mathrm{~g}, 0.01 \mathrm{~mol})$ was added. The mixture was stirred for about 15 minutes. The solution was concentrated by distillation. Green colored precipitates of the adduct were formed. The precipitates were filtered and dried in a vacuum desiccator. The composition of the adduct was established to be $\mathrm{VO}\left(\mathrm{C}_{5} \mathrm{H}_{7} \mathrm{O}_{2}\right)_{2}\left(\mathrm{C}_{6} \mathrm{H}_{7} \mathrm{~N}\right)$ by the elemental analysis, vanadium found $14.34 \%$; calculated $14.22 \%$.

\section{[Bis(acetylacetonato)(3-methylpyridine)oxovanadium(IV)] (10)}

The adduct was prepared by the same procedure followed for the compound 9 where 3methylpyridine $(0.93 \mathrm{~g}, 0.01 \mathrm{~mol})$ was used instead of 2-methylpyridine. The resulting solution was concentrated by distillation. The adduct obtained was dark green in color and its composition was established to be $\mathrm{VO}\left(\mathrm{C}_{5} \mathrm{H}_{7} \mathrm{O}_{2}\right)\left(\mathrm{C}_{6} \mathrm{H}_{7} \mathrm{~N}\right)$ by elemental analysis vanadium found $14.46 \%$; calculated $14.22 \%$.

\section{[Bis(acetylacetonato)(2-cyanopyridine)oxovanadium(IV)] (11)}

Bis(acetylacetonato)oxovanadium(IV) $(2.65 \mathrm{~g}, 0.01 \mathrm{~mol})$ was dissolved in chloroform (about $160 \mathrm{~mL}$ ). To the resulting solution 2-cyanopyridine ( $1.04 \mathrm{~g}, 0.01 \mathrm{~mol})$ was added. The mixture 
was stirred for about 30 minutes. The solution was concentrated to get the maximium yield. Green colored precipitates of the adduct were formed. The precipitates were filtered and dried in a vacuum desiccator over anhydrous calcium chloride. The composition of the adduct was established to be $\mathrm{VO}\left(\mathrm{C}_{5} \mathrm{H}_{7} \mathrm{O}_{2}\right)_{2}\left(\mathrm{C}_{6} \mathrm{H}_{4} \mathrm{~N}_{2}\right)$ by the elemental analysis, vanadium found $14.83 \%$; calculated $14.34 \%$.

\section{[Bis(acetylacetonato)(3-cyanopyridine)oxovanadium(IV)] (12)}

The adduct was prepared by the same procedure followed for the compound $\mathbf{1 1}$ where 3cyanopyridine $(1.04 \mathrm{~g}, 0.01 \mathrm{~mol})$ was used instead of 2-cyanopyridine. The adduct obtained was dark green in color and its composition was established to be $\mathrm{VO}\left(\mathrm{C}_{5} \mathrm{H}_{7} \mathrm{O}_{2}\right)_{2}\left(\mathrm{C}_{6} \mathrm{H}_{4} \mathrm{~N}_{2}\right)$ by elemental analysis, vanadium found $14.83 \%$; calculated $14.34 \%$.

\section{[Bis(acetylacetonato)(4-cyanopyridine)oxovanadium(IV)] (13)}

The adduct was prepared by the same procedure followed for the compound $\mathbf{1 1}$ where 4cyanopyridine $(1.04 \mathrm{~g}, 0.01 \mathrm{~mol})$ was used instead of 3-cyanopyridine. The dark green colored adduct was formed and its composition was established to be $\mathrm{VO}\left(\mathrm{C}_{5} \mathrm{H}_{7} \mathrm{O}_{2}\right)_{2}\left(\mathrm{C}_{6} \mathrm{H}_{4} \mathrm{~N}_{2}\right)$ by elemental analysis, vanadium found $14.83 \%$; calculated $14.34 \%$.

\section{[Bis(acetylacetonato)(quinoline)oxovanadium(IV)] (14)}

Bis(acetylacetonato)oxovanadium(IV) (2.65 g, $0.01 \mathrm{~mol})$ was dissolved in chloroform (about $160 \mathrm{~mL})$. To the resulting solution quinoline $(1.29 \mathrm{~g}, 0.01 \mathrm{~mol})$ was added. The mixture was stirred for about 10 minutes. After stirring for about 10 minutes the resulting solution was concentrated to get the maximium yield. Green colored precipitates of the adduct were formed. The precipitates were filtered and dried in a vacuum desiccator over anhydrous calcium chloride. The composition of the adduct was established to be $\mathrm{VO}\left(\mathrm{C}_{5} \mathrm{H}_{7} \mathrm{O}_{2}\right)_{2}\left(\mathrm{C}_{9} \mathrm{H}_{7} \mathrm{~N}\right)$ by the elemental analysis, vanadium found $12.82 \%$; calculated $12.92 \%$.

\section{[Bis(acetylacetonato)(isoquinoline)oxovanadium(IV)] (15)}

The adduct was prepared by the same procedure followed for the compound 14 where isoquinoline $(1.29 \mathrm{~g}, 0.01 \mathrm{~mol})$ was used instead of quinoline. The adduct obtained was dark green in color and its composition was established to be $\mathrm{VO}\left(\mathrm{C}_{5} \mathrm{H}_{7} \mathrm{O}_{2}\right)_{2}\left(\mathrm{C}_{7} \mathrm{H}_{9} \mathrm{~N}\right)$ by the elemental analysis, vanadium found $12.82 \%$; calculated $12.92 \%$.

\section{Antimicrobial studies}

Antifungal activity of the compounds has been studied to test their efficacy as antimicrobial agents in the Division of Plant Pathology, Sher-e-Kashmir University of Agriculture Sciences and Technology, Jammu (SKUAST-J).

\section{Antifungal assay}

The antifungal activity of the complex was tested by Poisoned food technique against the pathogenic fungus, Fusarium oxysporum. The pure culture of Fusarium oxysporum was obtained from Division of Plant Pathology, Sher-e-Kashmir University of Agriculture Sciences and Technology, Jammu (SKUAST-J). The stock culture was maintained on petri plates containing $50 \mathrm{~mL}$ of potato dextrose agar medium. Care was taken to ensure a regular supply of uncontaminated, seven days old culture until all the antifungal studies were over. The cultures were maintained at $28 \pm 1^{\circ} \mathrm{C}$ in a BOD incubator.

\section{Potato dextrose agar (PDA) medium}

Potato Dextrose Agar (PDA) medium was prepared with the following composition: 
- $\quad$ Peeled potato $200 \mathrm{~g}$

- Dextrose $20 \mathrm{~g}$

- Agar $220 \mathrm{~g}$

- Distilled water $1000 \mathrm{~mL}$

- $\mathrm{pH} 6$

The ingredients were taken in one litre Erlenmeyer's conical flask, plugged with non absorbent cotton and the mouth of flask was wrapped with aluminium foil. The contents of the flask were sterilized at $20 \mathrm{lb} /$ square inch pressure for 30 minutes and cooled to about $40{ }^{\circ} \mathrm{C}$. $10 \mathrm{mg}$ of the antibiotic streptomycin was added to this cooled medium and mixed thoroughly for prevention of bacterial activity.

\section{Poisoned food technique}

The test solutions were prepared by dissolving the compounds in chloroform and dichloromethane. The test solutions were mixed in the PDA and poured in the petri plates in sterilized conditions inside the Laminar flow. After solidification, the plates were inoculated with seven days old culture of pathogen, Fusarium oxysporum by placing $2 \mathrm{~mm}$ bit in the centre of the plates. The inoculated plates were incubated at $27^{\circ} \mathrm{C}$ for 4 days. The linear growth of fungus in controlled manner were recorded at different concentrations of the complexes. The growth inhibition of Fusarium oxysporum over control was calculated as:

$$
\% \text { Inhibition }(\mathrm{I})=\frac{C-T}{C} x 100
$$

$\mathrm{I}=$ percent inhibition; $\mathrm{T}=$ mean growth of fungus in $(\mathrm{mm})$ in treatment; $\mathrm{C}=$ control in $(\mathrm{mm})$.

\section{Results and Discussion}

Magnetic moment and molar conductance studies

The adduct complexes of bis(acetylacetonato)oxovanadium(IV) are microcrystalline solids which are light green in colour. These are insoluble in common organic solvents such as ethanol, acetone, benzene etc. However these are soluble in dimethyformamide and dimethylsulfoxide. On the basis of elemental analysis (Table 1) they have been assigned the general formula $\mathrm{VO}\left(\mathrm{C}_{5} \mathrm{H}_{7} \mathrm{O}_{2}\right)_{2} \mathrm{~L}[\mathrm{~L}=$ pyrrolidine, morpholine, 2,4,6-trimethylpyridine, 2,4, 2,6, 3,4, 3,5-dimethylpyridines, 2-ethylpyridine, 2-methylpyridine, 3-methylpyridine 2, 3, 4-cyanopyridine, quinoline, isoquinoline]. Conductance values of these complexes in DMF fall in the range of 1.85-7.75 $\mathrm{ohm}^{-1} \mathrm{~mole}^{-1} \mathrm{~cm}$. (Table 1). These values are lower than the values expected for any uni-univalent electrolytes in this solvent suggesting that these complexes are neutral and non-ionic in character. The magnetic moments of 1:1 complexes of bis(acetylacetonato)oxovanadium(IV) with heterocyclic nitrogen donor ligands fall in the range1.84-1.99B.M (Table 1) which is in agreement with magnetic moment values observed for octahedral geometry.

\section{Spectral studies}

\section{Infrared spectra}

Infrared spectra of the complexes were recorded in the range of $4000-400 \mathrm{~cm}^{-1}$ in order to investigate the mode of coordination of the acetylacetonate and other nitrogen donor ligands to the central metal ion. IR spectral bands of the adducts of bis(acetylacetonato) oxovanadium(IV) with pyrrolidine, morpholine, 2,4,6-trimethylpyridine, 2,4-, 2,6-, 3,4-, 3,5-dimethylpyridines 2-ethylpyridine, 2-methylpyridine, 3-methylpyridine 2,3,4-cyanopyridine, 
quinoline, isoquinoline have been studied and are presented in Table 2. The characteristic infrared peaks arising from the bonded ligands and the bis(acetylacetonato)oxovanadium(IV) group have been proved helpful in knowing their bonding mode.

Table 1. Molar conductance, magnetic moments and analytical data of 1:1 adducts with bis(acetylacetonato)oxovanadium(IV) with heterocyclic nitrogen donor ligands.

\begin{tabular}{|c|c|c|c|c|c|c|c|c|c|}
\hline \multirow[b]{2}{*}{ S.No } & \multirow[b]{2}{*}{ Name of the compound } & \multirow{2}{*}{ 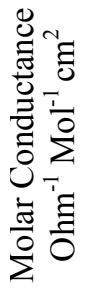 } & \multirow{2}{*}{ 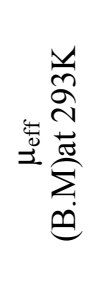 } & \multicolumn{3}{|c|}{$\%$ Found } & \multicolumn{3}{|c|}{$\%$ Calculated } \\
\hline & & & & $\mathrm{C}$ & $\mathrm{H}$ & $\mathrm{N}$ & $\mathrm{C}$ & $\mathrm{H}$ & $\mathrm{N}$ \\
\hline 1 & $\begin{array}{l}\text { Bis(acetylacetonato)(pyrrolidine) } \\
\text { oxovanadium(IV) }\end{array}$ & 2.35 & 1.77 & 51.02 & 5.35 & 4.73 & 50.00 & 6.89 & 4.17 \\
\hline 2 & $\begin{array}{l}\text { Bis(acetylacetonato)(morpholine) } \\
\text { oxovanadium(IV) }\end{array}$ & 1.90 & 1.72 & 46.01 & 6.53 & 3.65 & 47.73 & 6.58 & 3.98 \\
\hline 3 & $\begin{array}{l}\text { Bis(acetylacetonato) }(2,4,6- \\
\text { trimethylpyridine) } \\
\text { oxovanadium (IV) }\end{array}$ & 1.45 & 1.84 & 55.50 & 6.99 & 3.84 & 55.96 & 6.52 & 3.63 \\
\hline 4 & $\begin{array}{l}\text { Bis(acetylacetonato)(2,4- } \\
\text { dimethylpyridine) } \\
\text { oxovanadium(IV) }\end{array}$ & 2.10 & 1.82 & 56.22 & 5.94 & 3.46 & 54.84 & 6.23 & 3.76 \\
\hline 5 & $\begin{array}{l}\text { Bis(acetylacetonato) }(2,6- \\
\text { dimethylpyridine)oxovanadium(IV) }\end{array}$ & 2.25 & 1.79 & 54.77 & 6.87 & 3.28 & 54.84 & 6.23 & 3.76 \\
\hline 6 & $\begin{array}{l}\text { Bis(acetylacetonato) }(3,4- \\
\text { dimethylpyridine)oxovanadium(IV) }\end{array}$ & 2.40 & 1.82 & 55.35 & 6.11 & 3.65 & 54.84 & 6.23 & 3.76 \\
\hline 7 & $\begin{array}{l}\text { Bis(acetylacetonato)(3,5- } \\
\text { dimethylpyridine)oxovanadium(IV) }\end{array}$ & 1.56 & 1.81 & 55.67 & 6.47 & 3.27 & 54.84 & 6.23 & 3.76 \\
\hline 8 & $\begin{array}{l}\text { Bis(acetylacetonato)(2- } \\
\text { ethylpyridine) oxovanadium(IV) }\end{array}$ & 1.90 & 1.74 & 55.54 & 6.44 & 3.34 & 54.84 & 6.23 & 3.76 \\
\hline 9 & $\begin{array}{l}\text { Bis(acetylacetonato)(2- } \\
\text { methylpyridine)oxovanadium(IV) }\end{array}$ & 2.55 & 1.78 & 54.69 & 5.34 & 3.98 & 53.64 & 5.91 & 3.91 \\
\hline 10 & $\begin{array}{l}\text { Bis(acetylacetonato)(3- } \\
\text { methylpyridine) oxovanadium(IV }\end{array}$ & 2.05 & 1.83 & 53.40 & 6.58 & 3.29 & 53.64 & 5.91 & 3.91 \\
\hline 11 & $\begin{array}{l}\text { Bis(acetylacetonato)(2- } \\
\text { cyanopyridine)oxovanadium(IV) }\end{array}$ & 1.34 & 1.84 & 53.61 & 5.13 & 3.29 & 54.09 & 5.11 & 3.94 \\
\hline 12 & $\begin{array}{l}\text { Bis(acetylacetonato)(3- } \\
\text { cyanopyridine)oxovanadium(IV) }\end{array}$ & 1.35 & 1.83 & 53.59 & 5.38 & 3.05 & 54.09 & 5.11 & 3.94 \\
\hline 13 & $\begin{array}{l}\text { Bis(acetylacetonato)(4- } \\
\text { cyanopyridine) oxovanadium(IV) }\end{array}$ & 1.99 & 1.87 & 55.12 & 4.43 & 3.84 & 54.09 & 5.11 & 3.94 \\
\hline 14 & $\begin{array}{l}\text { Bis(acetylacetonato)(quinoline)ox } \\
\text { ovanadium(IV) }\end{array}$ & 1.25 & 1.85 & 56.54 & 5.01 & 3.79 & 57.87 & 5.37 & 3.55 \\
\hline 15 & $\begin{array}{l}\text { Bis(acetylacetonato)(isoquinoline) } \\
\text { oxovanadium(IV) }\end{array}$ & 1.20 & 1.77 & 56.21 & 5.01 & 3.75 & 57.87 & 5.37 & 3.55 \\
\hline
\end{tabular}


Table 2. Electronic and vibrational spectral data of 1:1 adducts of bis(acetylacetonato) oxovanadium(IV) with heterocyclic nitrogen donor ligands

\begin{tabular}{|c|c|c|c|c|c|c|c|}
\hline S.No & Name of the Adduct & $v_{1} \mathrm{~cm}^{-1}$ & $v_{2} \mathrm{~cm}^{-1}$ & $v_{3} \mathrm{~cm}^{-1}$ & $\begin{array}{c}\mathrm{N} \\
(\mathrm{V}=\mathrm{O})\end{array}$ & $\begin{array}{c}\mathrm{N} \\
\left(\mathrm{C}-\mathrm{CH}_{3}\right)\end{array}$ & $\begin{array}{c}\mathrm{N} \\
(\mathrm{C}-\mathrm{O})\end{array}$ \\
\hline 1 & $\begin{array}{l}\text { Bis(acetylacetonato)(pyrrolidine)ox } \\
\text { ovanadium(IV) }\end{array}$ & 13360 & 17691 & 28169 & 1012 & 930 & 1525 \\
\hline 2 & $\begin{array}{l}\text { Bis(acetylacetonato)(morpholine)ox } \\
\text { ovanadium(IV) }\end{array}$ & 13408 & 17321 & 27472 & 1006 & 928 & 1528 \\
\hline 3 & $\begin{array}{l}\text { Bis(acetylacetonato)( } 2 \text { - } \\
\text { methylpyridine)oxovanadium(IV) }\end{array}$ & 13313 & 17920 & 28411 & 1002 & 926 & 1537 \\
\hline 4 & $\begin{array}{l}\text { Bis(acetylacetonato)( } 3 \text { - } \\
\text { methylpyridine)oxovanadium(IV) }\end{array}$ & 13237 & 17052 & 27932 & 1008 & 932 & 1526 \\
\hline 5 & $\begin{array}{l}\text { Bis(acetylacetonato)(2- } \\
\text { ethylpyridine)oxovanadium(IV) }\end{array}$ & 13925 & 17056 & 27624 & 1010 & 922 & 1536 \\
\hline 6 & $\begin{array}{l}\text { Bis(acetylacetonato)(4- } \\
\text { cyanopyridine)oxovanadium(IV) }\end{array}$ & 13312 & 17063 & 27645 & 1015 & 923 & 1538 \\
\hline 7 & $\begin{array}{l}\text { Bis(acetylacetonato)( } 2,4- \\
\text { dimethylpyridine)oxovanadium(IV) }\end{array}$ & 13716 & 17345 & 27543 & 1011 & 922 & 1535 \\
\hline 8 & $\begin{array}{l}\text { Bis(acetylacetonato)(2,6- } \\
\text { dimethylpyridine)oxovanadium(IV) }\end{array}$ & 13421 & 43 & 2 & 1002 & 929 & 1527 \\
\hline 9 & $\begin{array}{l}\text { Bis(acetylacetonato) }(3,4- \\
\text { dimethylpyridine)oxovanadium(IV) }\end{array}$ & 13714 & 17456 & 27487 & 1009 & 924 & 1529 \\
\hline 10 & $\begin{array}{l}\text { Bis(acetylacetonato)(3,5- } \\
\text { dimethylpyridine)oxovanadium(IV) }\end{array}$ & 13341 & 17781 & 27321 & 1014 & 923 & 1539 \\
\hline 11 & $\begin{array}{l}\text { Bis(acetylacetonato })(2,4,6- \\
\text { trimethylpyridine) } \\
\text { oxovanadium(IV) }\end{array}$ & 13765 & 17654 & 27431 & 1007 & 921 & 1523 \\
\hline 12 & $\begin{array}{l}\text { Bis(acetylacetonato)(2- } \\
\text { cyanopyridine)oxovanadium(IV) }\end{array}$ & 13436 & 17786 & 27652 & 1000 & 925 & 1539 \\
\hline 13 & $\begin{array}{l}\text { Bis(acetylacetonato)(3- } \\
\text { cyanopyridine)oxovanadium(IV) }\end{array}$ & 13789 & 17452 & 27890 & 1005 & 926 & 1530 \\
\hline 14 & $\begin{array}{l}\text { Bis(acetylacetonato)(quinoline)oxo } \\
\text { vanadium(IV) }\end{array}$ & 13467 & 17435 & 27541 & 1015 & 924 & 1531 \\
\hline 15 & $\begin{array}{l}\text { Bis(acetylacetonato)(isoquinoline)o } \\
\text { xovanadium(IV) }\end{array}$ & 13423 & 17764 & 27431 & 998 & 923 & 1542 \\
\hline
\end{tabular}

Acetylacetonate vibrations

The IR spectra of the $\mathrm{VO}(\mathrm{acac})_{2}$ complexes have been extensively studied. The peaks of interest in the FT-IR spectra of the $\mathrm{VO}(\mathrm{acac})_{2}$ are the intense band observed at $1516 \mathrm{~cm}^{-1}$ having a shoulder at $1588 \mathrm{~cm}^{-1}$, the band at $1370 \mathrm{~cm}^{-1}$ which are assigned as $\mathrm{C}-\mathrm{O}$ stretching vibrations and the stretching vibrations of the $\mathrm{V}=\mathrm{O}$, vanadyl bond are observed at $991 \mathrm{~cm}^{-1}$. This is within the usually observed range $95-999 \mathrm{~cm}^{-1}$ for six coordinate oxovanadium(V) complex. The in-plane vibration of the cyclic fragment is observed at $934 \mathrm{~cm}^{-1}$ while the out-of-plane bending vibration is observed as a doublet at 788 and $797 \mathrm{~cm}^{-1}$. In the range 1416 and $1112-934 \mathrm{~cm}^{-1}$ the FT-IR spectra exhibit bands corresponding to $\mathrm{CH}_{3}$ groups. The spectra contain strong and sharp band which is assigned as vibration corresponding to the C-C-C angle ${ }^{4}$ at $1285 \mathrm{~cm}^{-1}$. 


\section{Ligand vibrations}

Infrared peaks arising due to the coordinated ligands have been found to be modified and show considerable shifts from their positions found in uncoordinated state. A comparison of the infrared spectra of the adducts prepared with those of the free ligands clearly reveals that most of the absorption bands due to the free ligands are shifted in their respective adducts.

\section{Methyl and dimethylpyridine complexes}

A comparison of the infrared spectral data of the adducts of vanadium(IV)dithiocarbamates with methyl and dimethyl pyridines with those of the free ligands reveals that out of plane $\mathrm{C}-\mathrm{H}$ deformation vibration of the free ligand show a slight negative shift $\left(5-10 \mathrm{~cm}^{-1}\right)$ in their respective adducts. However, a considerable positive shift in the important modes such as ring $\mathrm{C}-\mathrm{C}, \mathrm{C}-\mathrm{N}$ stretching vibration, $\mathrm{C}-\mathrm{H}$ in plane and ring in and out of plane deformation vibrations were observed, indicating the coordination of ligand to the metal ion ${ }^{5}$.

\section{Trimethylpyridine complexes}

Most of the infrared absorption bands due to 2,4,6-trimethylpyridine appear at considerably altered frequencies in the complexes under study. The ring $\mathrm{C}-\mathrm{C}, \mathrm{C}-\mathrm{N}$ stretching vibration, $\mathrm{C}-\mathrm{H}$ in plane deformation vibration show a negative shift on complexation suggesting the coordination of ligand to the metal ion through its nitrogen atom ${ }^{5}$. The IR spectra of adducts of with nitrogen donors show three absorption bands at $940-970 \mathrm{~cm}^{-1}, 998-1015 \mathrm{~cm}^{-1}$ and $1525-1546 \mathrm{~cm}^{-1}$ which are assigned to $v\left(\mathrm{C}-\mathrm{CH}_{3}\right), v(\mathrm{~V}=\mathrm{O})$, vs $(\mathrm{C}-\mathrm{O})$ stretching vibrations respectively. There is a positive shift of $10-30 \mathrm{~cm}^{-1}$ in comparison to free ligands.

\section{Morpholine complex}

The coordination of morpholine as monodentate ligand can be detected by comparing $v$ N-H \& vC-O-C stretching vibrations of the coordinated ligand in the IR spectra with that of corresponding vibration of free ligand which appear at 3340 and $1095 \mathrm{~cm}^{-1}$ respectively. Shift in $\mathrm{N}-\mathrm{H}$ stretching vibration to lower frequency in conjunction with the slight + ive shift in C-O-C spectral vibrations indicate that the morpholine is coordinated through the nitrogen atom ${ }^{6,7}$.

\section{Cyanopyridine complexes}

Cyanopyridine possess two different donor sites and can act as monodentate or bidentate ligand. It acts as monodentate ligand when it coordinates through its ring $\mathrm{N}$-atom or nitrile $\mathrm{N}$-atom. It can, however, also behave as bidentate bridging ligand by using both types of nitrogen atoms. 2-, 3- and 4-cyanopyridines are reported to coordinate to the metal through their ring nitrogen atom only since $v \mathrm{C}-\mathrm{N}$ does not vary on coordination. It is established that there should be an increase in $\mathrm{vC}-\mathrm{N}$ by atleast ${ }^{8} 30 \mathrm{~cm}^{-1}$ if a cyanopyridine ligand coordinates to the metal using nitrile $N$-atom but on the other hand, if $-\mathrm{CN}$ group coordinates using $\pi$-electrons, $v \mathrm{C}-\mathrm{N}$ must show a negative shift ${ }^{9}$.

The $\mathrm{C}=\mathrm{N}$ stretching frequencies in free cyanopyridines fall at 2240 and $2225 \mathrm{~cm}^{-1}$ respectively. But in the complexes these bands have been found to shift to higher energy side which suggests that the metal is coordinated to ring nitrogen.

\section{Pyrrolidine complex}

Pyrrolidine has one ring nitrogen through which the interaction with the metal can occur. In pyrrolidine $v \mathrm{~N}-\mathrm{H}$ band occur at $3450 \mathrm{~cm}^{-1}$ while in the complex, this has been shifted to higher frequency indicating positive shifts which indicates the coordination of ligand nitrogen to the metal ${ }^{10}$. 


\section{2-Ethylpyridine complex}

Ethyl pyridines have only ring nitrogen through which the interaction with the metal can occur. In 2-ethyl pyridine ring breathing band occur at $995 \mathrm{~cm}^{-1}$ while in the complex, this has been shifted to $1044 \mathrm{~cm}^{-1}$ indicating positive shifts conforming coordination of ligand to the metal ${ }^{11}$.

\section{Quinoline and isoquinoline complexes}

In free quinoline, the peaks at 1590,1565, 1495 and $1435 \mathrm{~cm}^{-1}$ have been assigned to ring stretching vibrations similarly in the free isoquinoline ring stretching frequencies ${ }^{12}$ occur at $1630,1590,1500$ and $1465 \mathrm{~cm}^{-1}$. These values show a positive shift in their positions which suggests that quinoline and isoquinoline ligands in the complexes coordinated to the metal through their respective ring nitrogen atoms, the only coordinating site present in them.

\section{Electronic spectra}

Oxovanadium(IV) complexes of various 3-substituted 2,4-pentanediones [ $\mathrm{VO}\left(\mathrm{H}_{3} \mathrm{CCOCHR}\right.$ $\left.\left.\mathrm{COCH}_{3}\right)_{2}\right]$, where $\mathrm{R}=\mathrm{CH}_{3}, \mathrm{C}_{2} \mathrm{H}_{5}, \mathrm{i}-\mathrm{C}_{3} \mathrm{H}_{7}, \mathrm{n}-\mathrm{C}_{4} \mathrm{H}_{9}, \mathrm{i}-\mathrm{C}_{4} \mathrm{H}_{9}, \mathrm{C}_{6} \mathrm{H}_{5}, \mathrm{CH}_{3} \mathrm{CO}, \mathrm{C}_{6} \mathrm{H}_{5} \mathrm{CH}_{2}$, exhibit three spin allowed transitions in the regions $10600-15630 \mathrm{~cm}^{-1} 16400-18100 \mathrm{~cm}^{-1}$ and 19000 $25000 \mathrm{~cm}^{-1}$ and have been assigned to $\mathrm{e}_{\pi}{ }^{*} \leftarrow \mathrm{b}_{2}, \mathrm{~b}_{1} \leftarrow \mathrm{b}_{2}$ and $\mathrm{a}_{1} \leftarrow \mathrm{b}_{2}$ transitions respectively. On adduct formation with 4-methylpyridine the band positions experienced a slight shift to lower energies ${ }^{13}$. VO(IV) polychelates show bands at 10845,19230 and $26180 \mathrm{~cm}^{-1}$ corresponding to transitions $\mathrm{d}_{\mathrm{xy}}\left(\mathrm{b}_{2}\right) \rightarrow \mathrm{d}_{\mathrm{xz}} \mathrm{d}_{\mathrm{yz}}\left(\mathrm{e}^{*}\right), \mathrm{d}_{\mathrm{xy}}\left(\mathrm{b}_{2}\right) \rightarrow \mathrm{d}_{\mathrm{x} 2-\mathrm{y} 2}\left(\mathrm{~b}_{1}{ }^{*}\right)$ and $\mathrm{d}_{\mathrm{xy}}\left(\mathrm{b}_{2}\right) \rightarrow \mathrm{d}_{\mathrm{z}}{ }^{2}\left(\mathrm{a}_{1}{ }^{*}\right)$ respectively for octahedral stereochemistry ${ }^{13}$. The adducts $\left[\mathrm{VOL}_{2}\right]$.py and $[\mathrm{VO}(\mathrm{OH})(\mathrm{L})$ $\left.(\text { py })_{2}\right] \mathrm{OH} . \mathrm{H}_{2} \mathrm{O}$ derivatives where $\mathrm{L}=(\mathrm{RNCS})_{2}$ show three bands in the electronic spectra occurring at $14000 \mathrm{~cm}^{-1}, 20230-20400 \mathrm{~cm}^{-1}$ and $24000 \mathrm{~cm}^{-1}$ and are attributed to ${ }^{2} \mathrm{~b}_{2} \rightarrow{ }^{2} \mathrm{e},{ }^{2} \mathrm{~b}_{2}$ $\rightarrow{ }^{2} b_{1}$ and ${ }^{2} b_{2} \rightarrow{ }^{2} a_{1}$ respectively ${ }^{14}$. Complexes of oxovanadium(IV) with 2,3-dihydrazinoquinoxaline (DHQ) show three bands at 12150, 21505, $23094 \mathrm{~cm}^{-1}$ and the fourth band at $32786 \mathrm{~cm}^{-1}$. The first three bands are assigned ${ }^{14}$ to ${ }^{2} \mathrm{~b}_{2} \rightarrow{ }^{2} \mathrm{e},{ }^{2} \mathrm{~b}_{2} \rightarrow{ }^{2} \mathrm{~b}_{1}$ and ${ }^{2} \mathrm{~b}_{2} \rightarrow{ }^{2} \mathrm{a}_{1}$. [VO(Nfth) $\mathrm{H}_{2} \mathrm{O}$ ] shows two bands, 11910 and $15625 \mathrm{~cm}^{-1}$, which are assigned to ${ }^{2} \mathrm{~b}_{2} \rightarrow{ }^{2} \mathrm{e}$ and ${ }^{2} b_{1}$ transitions respectively on the basis of octahedral geometry of the complex. The other high energy band at $24510 \mathrm{~cm}^{-1}$ is due to the charge transfer transition ${ }^{15}$.

The electronic spectra of the adducts of bis(acetylacetonato)oxovanadium(IV) with monodentate nitrogen bases, prepared in the present work, were recorded in dimethylformamide. The adducts of bis(acetylacetonato)oxovanadium(IV) show three bands in the range $11690-14380 \mathrm{~cm}^{-1}, 15710-19010 \mathrm{~cm}^{-1}$ and 20100-29300 $\mathrm{cm}^{-1}$ and are assigned to $\mathrm{e} \leftarrow$ $\mathrm{b}_{2}, \mathrm{~b}_{1} \leftarrow \mathrm{b}_{2}$ and $\mathrm{a}_{1} \leftarrow \mathrm{b}_{2}$ transitions respectively. These bands are characteristic of oxovanadium(IV) complexes in octahedral environment ${ }^{13,14}$ (Table 2).

\section{Antifungal activity}

The in vitro biological screening effects of the investigated compounds were tested against the pathogen Fusarium oxysporum by the poisoned food method using Potato Dextrose Agar (PDA) nutrient as the medium. The linear growth of fungus in control and treatment were recorded at different concentrations of the complexes.

Table 3 shows that on increasing the concentration of the complexes, the colony diameter of the fungus decreases and hence percent inhibition increases. On doubling the concentration of the complexes the percent inhibition also doubles, which shows linear relationship between concentration and percent inhibition. The increase in antimicrobial activity is due to faster diffusion of metal complexes as a whole through the cell membrane or due to combined activity effect of the metal and the ligand. 
Table 3. In vitro evaluation of complexes against Fusarium oxysporum mean colony diameter, $\mathrm{C}=6 \mathrm{~cm}$

\begin{tabular}{llccc}
\hline S. No & \multicolumn{1}{c}{ Name of the complex } & $\begin{array}{c}\text { Concentration } \\
\mathrm{ppm}\end{array}$ & $\begin{array}{c}\text { Colony } \\
\text { diameter } \\
\mathrm{cm}\end{array}$ & $\begin{array}{c}\text { \% Inhibition } \\
\mathrm{I}=[(\mathrm{C}-\mathrm{T}) / \mathrm{C}] \\
\times 100\end{array}$ \\
\hline 1. $\quad$ Bis(acetylacetonato)(2- & 50 & 2 & 67 \\
& methylpyridine) oxovanadium(IV) & 100 & 1.7 & 72 \\
& & 150 & 1.6 & 73 \\
2. $\quad$ Bis(acetylacetonato)(3- & 200 & 1.4 & 77 \\
& methylpyridine)oxovanadium(IV) & 50 & 2 & 67 \\
& & 100 & 1.8 & 70 \\
3. $\quad$ Bis(acetylacetonato)(3,5- & 150 & 1.6 & 73 \\
& dimethylpyridine)oxovanadium(IV) & 100 & 1.4 & 77 \\
& & 150 & 2 & 67 \\
4. $\quad$ Bis(acetylacetonato)(4-cyanopyridine) & 200 & 1.7 & 72 \\
& oxovanadium(IV) & 1.6 & 73 \\
& & 100 & 2.3 & 78 \\
& & 150 & 1.8 & 70 \\
& & 200 & 1.4 & 73 \\
\hline
\end{tabular}

Such increased activity of the metal complexes can be explained on the basis of Overtone's concept ${ }^{16}$ and Tweedy's chelation theory ${ }^{17}$. The lipid membrane that surrounds the cell favours passage of only lipid soluble materials due to liphophilicity being an important factor which controls the antimicrobial activity. On chelation, the polarity of the metal ion will be reduced to a greater extent due to overlap of the ligand orbital and partial sharing of the positive charge of the metal ion with donor group. Antifungal activities of $\left(\mathrm{C}_{5} \mathrm{H}_{7} \mathrm{O}_{2}\right)_{2}\left(\mathrm{C}_{6} \mathrm{H}_{7} \mathrm{~N}\right) \mathrm{VO},\left(\mathrm{C}_{5} \mathrm{H}_{7} \mathrm{O}_{2}\right)_{2}\left(\mathrm{C}_{6} \mathrm{H}_{7} \mathrm{~N}\right) \mathrm{VO}$, $\left(\mathrm{C}_{5} \mathrm{H}_{7} \mathrm{O}_{2}\right)_{2}\left(\mathrm{C}_{7} \mathrm{H}_{9} \mathrm{~N}\right) \mathrm{VO}$ and $\left(\mathrm{C}_{5} \mathrm{H}_{7} \mathrm{O}_{2}\right)\left(\mathrm{C}_{6} \mathrm{H}_{4} \mathrm{~N}_{2}\right) \mathrm{VO}$ are shown in the Figure 1(a to d).

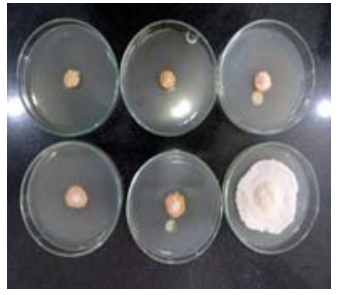

Figure 1 (a). Antifungal activity of complex $\left(\mathrm{C}_{5} \mathrm{H}_{7} \mathrm{O}_{2}\right)_{2}\left(\mathrm{C}_{6} \mathrm{H}_{7} \mathrm{~N}\right) \mathrm{VO}$

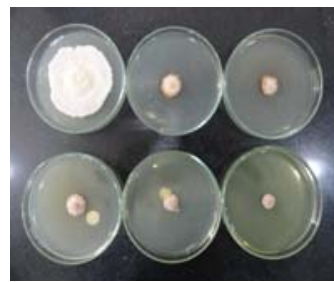

Figure 1 (c). Antifungal activity of complex $\left(\mathrm{C}_{5} \mathrm{H}_{7} \mathrm{O}_{2}\right)_{2}\left(\mathrm{C}_{7} \mathrm{H}_{9} \mathrm{~N}\right) \mathrm{VO}$

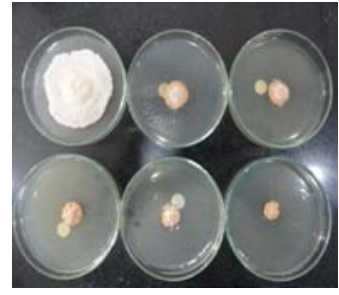

Figure 1 (b). Antifungal activity of complex $\left(\mathrm{C}_{5} \mathrm{H}_{7} \mathrm{O}_{2}\right)_{2}\left(\mathrm{C}_{6} \mathrm{H}_{7} \mathrm{~N}\right) \mathrm{VO}$

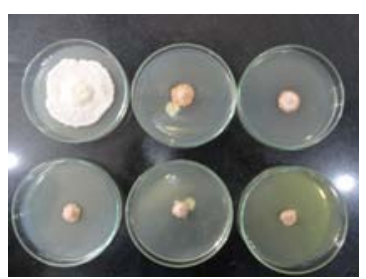

Figure 1 (d). Antifungal activity of complex $\left(\mathrm{C}_{5} \mathrm{H}_{7} \mathrm{O}_{2}\right)\left(\mathrm{C}_{6} \mathrm{H}_{4} \mathrm{~N}_{2}\right) \mathrm{VO}$ 


\section{Conclusion}

The results obtained from various physicochemical and spectral techniques suggests that the adducts of bis(acetylacetonato)oxovanadium(IV) with heterocyclic nitrogen donor ligands with octahedral geometry around oxovanadium(IV).

\section{References}

1. Manuel Ribeiro da Silva A V and Maria Luisa Ferrso C C H, Pure Appl Chem., 1988, 60(8), 1225.

2. Albert G N, Brown P D, Esko I K and Jokiniemi J K, J Phys Chem B, 2001, 105(45), 11067-11075; DOI:10.1021/jp0114135

3. Radon M, Srebro M and Broclawik E, J Chem Theory Comput., 2009, 5(5), 1237 1244; DOI:10.1021/ct800571y

4. Ndwandwe S, Patrick Tshibangu and Ezekiel Dixon Dikio, Int J Electrochem Sci., 2011, 6, 749-760.

5. Furlani $\mathrm{C}$ and Luciani M L, Inorg Chem., 1968, 7(8), 1586-1592; DOI:10.1021/ic50066a021

6. Ahuja I S and Garg A, Inorg Nucl Chem Nett., 1971, 7, 937.

7. Marcotrigiano C and Pellacani G C,, Inorg Nucl Chem Lett., 1973, 9, 957-960.

8. Ahuja I S and Singh R, J Inorg Nucl Chem., 1974, 36(7), 1505-1513; DOI:10.1016/0022-1902(74)80614-7

9. Ford P C and Clarke R E, Chem Cumm., 1968, 1109-1110; DOI: $10.1039 / \mathrm{C} 19680001109$.

10. Rao P V and Naresaian A V, Indian J Chem., 2003, 12(A), 1896-1899.

11. Green J H S and Barnard P W B, J Chem Soc., 1963, 12, 640-643; DOI:10.1039/JR9630000640

12. Samuel C W J and Mcnerney J C, J Mol Spectros., 1970, 34(1), 56-77; DOI:10.1016/0022-2852(70)90075-5

13. Aswar A S, Bansod A D, Aswale S R and Mamdlik P R, Indian J Chem., 2004, 43A, 1892-1896.

14. Rani D S, Ananthalakshmi P V and Jayatyagaraju V, Indian J Chem., 1999, 38A, 843-846.

15. Doadrio A L, Sotelo J and Ruano A F, Quim Nova., 2002, 25(4), 525-528.

16. Dharamraj N, Viswanathamurthi P and Natarajan K, Trans Met Chem., 2001, 26, 105.

17. Mishra L and Singh V K, Indian J Chem., 1993, 32A, 446. 